\title{
Prostaglandin synthesis and metabolism in the human uterus and midtrimester fetal tissues
}

\author{
G. Falkay, J. Herczeg and M. Sas \\ Department of Obstetrics and Gynecology, WHO Collaborative Centre in Clinical Research on \\ Human Reproduction, University Medical School of Szeged, H-6701 P.O.B. 438, Hungary
}

\begin{abstract}
Summary. Prostaglandin (PG) synthesis and metabolism was studied in human fetal kidney, lung, small intestine, heart, brain and liver (gestational ages: 10, 12, 14, 18 and 23 weeks) and pregnant uterus (4-40 weeks of pregnancy). PG synthesis was increased in the myometrium during pregnancy while the capacity of metabolism did not change. PG synthesis increased in lung and kidney (4-fold), brain (20-fold) and small intestine (2-fold) but not in heart or liver. Metabolic activity increased only in fetal kidney and lung.
\end{abstract}

\section{Introduction}

Prostaglandins (PGs) are thought to be virtually ubiquitous in mammalian tissues and to exert a wide variety of striking physiological and pharmacological actions. They are derived from certain $\mathrm{C}_{20}$ polyunsaturated fatty acids through reactions catalysed by PG synthetase. Tissues produce different types and amounts of PGs and the various PGs have different biological actions. Karim \& Devlin (1967) first suggested that the PG found during labour in human amniotic fluid could originate from the decidua. Willman \& Collins (1978) and Falkay, Herczeg \& Sas (1978b) have shown that the incubation of pregnant human myometrium with the natural PG precursor arachidonic acid results in the formation of PGs. The presence of prostaglandin dehydrogenase (PGDH) has also been demonstrated in homogenates of maternal and fetal tissues (Keirse \& Turnbull, 1975; Keirse, Williamson \& Turnbull, 1975), and a significant change of PGDH activity in human placenta during the early period of pregnancy has been shown in vitro (Falkay \& Sas, 1977b, 1978). Pace-Asciak (1977a, b) has indicated certain periods of development of fetal sheep lung and kidney which involve characteristic changes in PG synthetase and PGDH: one such period has been termed the "critical prostaglandin period" of development and suggests an intrinsic need of the developing organ for PGs. The aim of our present investigation was to study the synthesis and metabolism of PGs in pregnant human uterus and fetal lung, kidney, small intestine, liver, heart and brain at different stages of pregnancy.

\section{Materials and Methods}

Myometrial strips were obtained from non-pregnant human uteri which had been removed because of fibromata or other non-malignant conditions. All were from women in their reproductive years. Myometrial samples from pregnant women were excised from the edge of the surgical incision in the lower segment during elective Caesarean sections for fetal indications. Fetal tissues were obtaineo from 5 fetuses, aged 10,12, 14, 18 and 23 weeks, which were 
aborted for socio-economic reasons by hysterectomy (Weeks 14, 18 and 23) or by Hegar dilatation and curettage (Weeks 10 and 12). Meticulous care was exercised when pieces of different fetal origin were separated. The stage of pregnancy was estimated from the last menstrual period. Tissue samples were placed in a dry container in an ice-bath and stored at $-70^{\circ} \mathrm{C}$; there was no loss of enzyme activities even when the tissues were kept for 2 weeks.

Assay of prostaglandin synthetase. The tissue samples were homogenized with 10 volumes of $0.1 \mathrm{M}$-Tris- $\mathrm{HCl}$ buffer $\left(\mathrm{pH} \mathrm{7.8)}\right.$, and then centrifuged for $10 \mathrm{~min}$ at $10000 \mathrm{~g}$ and $4^{\circ} \mathrm{C}$. The supernatant fraction was again centrifuged, at $105000 \mathrm{~g}$ for $60 \mathrm{~min}$, and the precipitated microsomes were resuspended in the Tris- $\mathrm{HCl}$ buffer, $\mathrm{pH} 7.8$. The assay of $\mathrm{PG}$ synthetase activity (EC 1.14.99.1) was based on methods reported by Tai, Tai \& Hollander (1976) and Falkay, Herczeg \& Kovács (1978a). The assay mixture $(2.0 \mathrm{ml})$ contained $0.1 \mathrm{M}-\mathrm{Tris}-\mathrm{HCl}, \mathrm{pH}$ $7.8,2.0 \mathrm{~mm}$-L-adrenaline, $2.0 \mathrm{~mm}$-glutathione $\left[1{ }^{14} \mathrm{C}\right]$ arachidonic acid $(0.1 \mu \mathrm{Ci}, 1.0 \mu \mathrm{M}$, sp. act. $60.2 \mathrm{mCi} / \mathrm{mmol}$ : Radiochemical Centre, Amersham, England) and $2.5-3.0 \mathrm{mg}$ microsomal protein. After incubation at $37^{\circ} \mathrm{C}$ for $30 \mathrm{~min}$, the reaction mixture was acidified $(1.0 \mathrm{M}-\mathrm{HCl})$ and extracted twice with $10 \mathrm{ml}$ ethyl acetate. The organic layer was dried under nitrogen and the residue was spotted on silica-gel $G$ thin-layer chromatography (t.l.c.) plates and developed with chloroform-methanol-acetic acid (18:1:1 by vol.) as the solvent system, together with authentic standards of PGF-2 $\alpha$ and PGE-2 (Upjohn Company, Kalamazoo, U.S.A.). The PGs were located by visualization with phosphomolybdic acid, and scanned for radioactivity. The $R_{\mathrm{F}}$ values were as follows: PGF-2 $\alpha, 0 \cdot 16$; PGE-2, 0.34; and arachidonic acid, 0.87 . The identified PGs and arachidonic acid were transferred to a scintillation vial and the radioactivity was determined by liquid-scintillation counting. The activity of PG synthetase is given as pmol PG formed $/ 30 \mathrm{~min} / \mathrm{mg}$ protein. Protein was estimated by the method of Lowry, Rosebrough, Farr \& Randall (1951).

Assay of 15-hydroxyprostaglandin dehydrogenase ( $P G D H)$. Details of the procedure and a complete evaluation of the assay of this enzyme (EC 1.1.1.141) for application to human fetal-placental tissues have been published (Falkay \& Sas 1977a). Briefly, the tissue samples were homogenized with 4 volumes Bücher medium $\left(\mathrm{KH}_{2} \mathrm{PO}_{4} 20.0 \mathrm{mM}, \mathrm{K}_{2} \mathrm{HPO}_{4} 72.0 \mathrm{mM}\right.$, nicotinamide $28.0 \mathrm{mM}, \mathrm{MgCl}_{2} 4.0 \mathrm{mM}$ ). The whole homogenates were centrifuged at $10000 \mathrm{~g}$, and $2.0 \mathrm{ml}$ supernatant were incubated with $0.1 \mu \mathrm{M}-\left[{ }^{3} \mathrm{H}\right] \mathrm{PGF}-2 \alpha$ (sp. act. $15.0 \mathrm{mCi} / \mathrm{mmol}$ : Radiochemical Centre) for $5 \mathrm{~min}$ at $37^{\circ} \mathrm{C} ; 4.0 \mathrm{~mm}$-NAD was supplied as cofactor. The products of the incubation (15-keto-PGF-2 $\alpha$ and 15-keto-13,14-dihydro-PGF-2 $\alpha$ ) and unmetabolized PGF-2 $\alpha$ were separated by t.l.c. (silica-gel G) in benzene-dioxan-acetic acid (10:10:1, by vol.). Detection and counting of radioactivity were as described above. Metabolism of PGF-2 $\alpha$ is expressed as pmol substrate metabolized $/ \mathrm{h} / \mathrm{mg}$ protein.

\section{Results}

The formation and degradation of PGs by non-pregnant and pregnant myometrial tissues are shown in Table 1. PG synthesis increased as pregnancy progressed but PGDH activity did not change markedly. The activities of the synthetic and metabolizing enzymes in fetal kidneys, lung, heart and small intestine as a function of age are shown in Text-fig. 1. In fetal kidney (Text-fig. 1a), PGF- $2 \alpha$ formation hardly changed until Week 23 but the formation of PGE- 2 increased linearly with age, as did PGDH. Like that in kidney, total PG synthetase activity in fetal lung at Week 23 was approximately 4 times that at Week 10 (Text-fig. 1b). The synthesis of PGE-2 rose about 15 -fold and was a generally linear increase, but there was not a linear change for PGDH or PGF- $2 \alpha$ synthetase. There were no characteristic changes in fetal heart tissue (Text-fig. 1c). The activity of PGDH was low (conversion about $10 \%$ compared to control inactivated by boiling at $100^{\circ} \mathrm{C}$ before incubation). The changes in fetal small intestines were also slight (Text-fig. 1d), there being an approximately 2 -fold increase in total PG synthesis from 


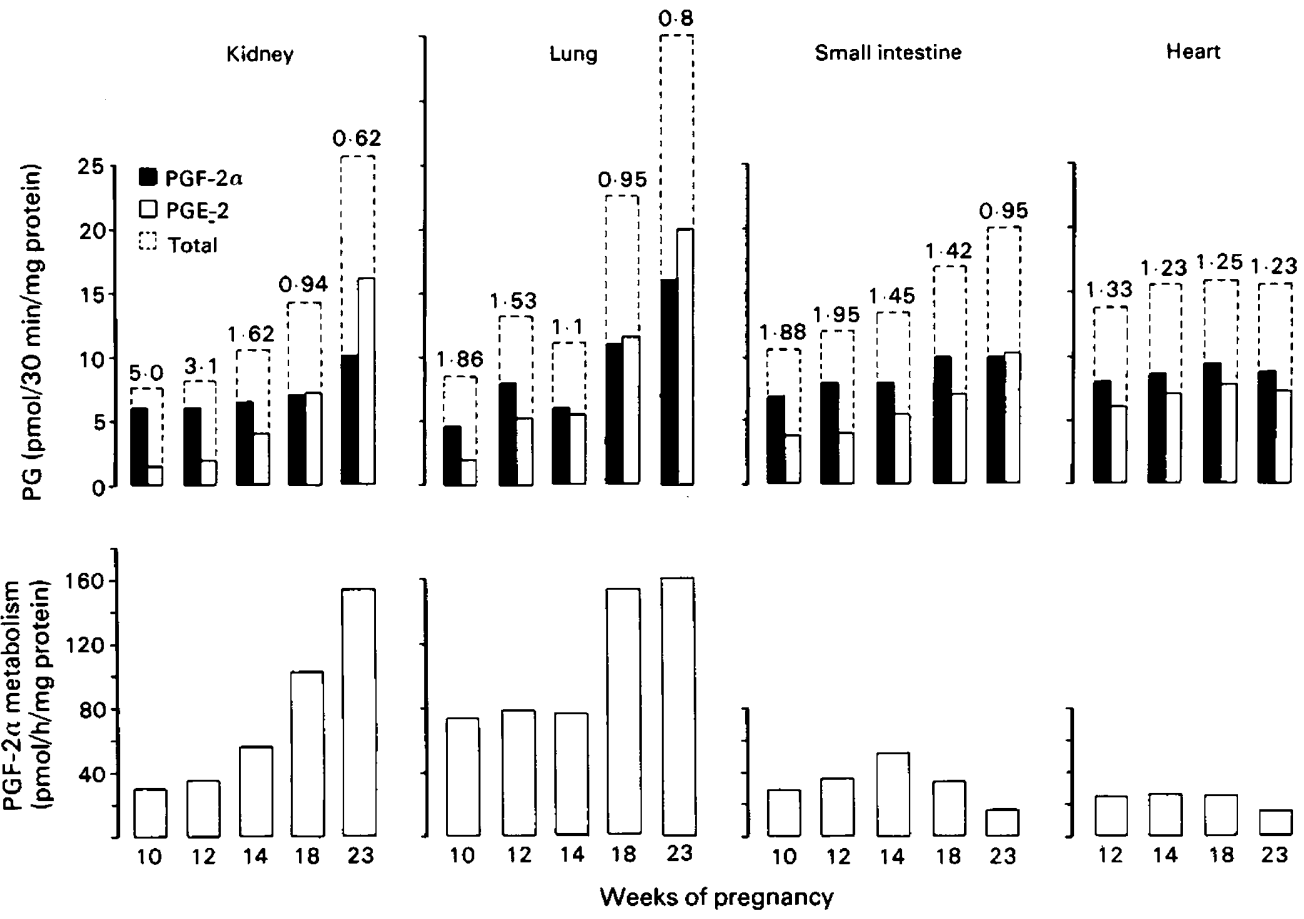

Text-fig. 1. Activities of PG synthetases and 15-hydroxyprostaglandin dehydrogenase in human fetal kidney, lung, small intestine and heart tissues during pregnancy. Each column represents duplicate experiments on tissue from 1 fetus (the variation was 5-15\%) and the values given above the upper columns are the ratios of PGF-2 $\alpha$ : PGE-2 synthesizing activities.

Weeks 10 to 23. In fetal brain tissues PG synthesis was demonstrated successfully only at Weeks 14,18 and 23 (i.e. $4 \cdot 2,7.8$ and $25.5 \mathrm{pmol} P G / 30 \mathrm{~min} / \mathrm{mg}$ protein) and there was no alteration of the PGF-2 $\alpha$ :PGE-2 ratio. There was a low PGDH activity $(14.8 \mathrm{pmol} / \mathrm{h} / \mathrm{mg}$ protein) at Week 23 of pregnancy. PG synthesis could not be detected in the liver of any of the fetuses and the \% conversion was not different from that in the inactivated control tissue.

Table 1. The activities of PG synthetase and 15-hydroxyprostaglandin dehydrogenase (PGDH) in human myometrium in vitro

\begin{tabular}{|c|c|c|c|c|c|c|}
\hline \multirow[b]{2}{*}{ Enzyme activity } & \multirow[b]{2}{*}{ Not pregnant } & \multicolumn{5}{|c|}{ Weeks of pregnancy } \\
\hline & & $4-6$ & $12-14$ & $16-18$ & $25-28$ & $38-40$ \\
\hline $\begin{array}{l}\text { PG synthetase } \\
\text { (pmol } / 30 \mathrm{~min} / \\
\text { mg protein) }\end{array}$ & $10 \cdot 1 \pm 1+1$ & $\begin{array}{c}18 \cdot 3 \pm 2 \cdot 2 \\
(4)\end{array}$ & $36 \cdot 1 \pm 3 \cdot 7$ & $\begin{array}{c}72 \cdot 5 \pm 6 \cdot 7 \\
(4)\end{array}$ & $\begin{array}{c}92 \cdot 0 \pm 6 \cdot 1 \\
(5)\end{array}$ & $\begin{array}{c}151 \cdot 0 \pm 7 \cdot 7 \\
(10)\end{array}$ \\
\hline $\begin{array}{l}\text { PGDH } \\
\text { (pmol/h/mg } \\
\text { protein) }\end{array}$ & $\underset{(8)}{42 \cdot 2 \pm 5 \cdot 3}$ & $\begin{array}{c}38 \cdot 6 \pm 5 \cdot 2 \\
(4)\end{array}$ & $\begin{array}{c}46 \cdot 7 \pm 8 \cdot 6 \\
(5)\end{array}$ & $\begin{array}{c}44 \cdot 5 \pm 4 \cdot 5 \\
(4)\end{array}$ & ${ }_{(5)}^{42 \cdot 0 \pm 5.6}$ & $\begin{array}{c}46 \cdot 6 \pm 3 \cdot 4 \\
(10)\end{array}$ \\
\hline
\end{tabular}

Values are mean \pm s.e.m. for the number of samples indicated in parentheses.

Analysis of variance was performed. The between-groups and within-groups variances for PG synthesis were significantly different $\left(\mathrm{F}=97.854\right.$, d.f. $._{1}=5$, d.f. $\left.._{2}=30, P<0 \cdot 001\right)$. 


\section{Discussion}

Numerous investigators have measured PGs, mainly PGF, in pregnancy and at term by sampling maternal peripheral blood or amniotic fluid. The literature appears to be controversial on some aspects of PG content of biological compartments of human pregnancy (see review by Keirse, 1978) and the origin of the PGs (myometrium, decidua, fetal organs) can be investigated only indirectly. The main drawback of the previous studies is that any invasion of the gestation sac (aminocentesis, venous blood sampling) will result in PG release, influencing measurements considerably (Piper \& Vane, 1971). PGs should be considered as local hormones, which are synthesized at or near their sites of action and are inactivated locally (Needelman, 1978). In the present study an in-vitro technique was used because this potentially allows measurement of the production of labelled PGs, rather than the concentration of endogenous PGs in the tissues, thereby avoiding possible errors arising from the rapid synthesis of unlabelled PGs during handling.

The results reported here demonstrate that in human myometrium the synthesis of PGF- $2 \alpha$ and PGE-2 increases significantly with the duration of pregnancy, although there is no change in metabolism. This chain of events will result in an increased working potential of the myometrium.

Apart from the production of primary PGs, uterine tissues obtained from pregnant rhesus monkeys have been shown to produce thromboxane B-2 in vitro (Mitchell, Hicks, Thorburn \& Robinson, 1978), although these authors suggested that PGs rather than thromboxanes are more intimately involved in the onset of labour. However, under our experimental conditions the production of thromboxane B- 2 by human pregnant myometrium and fetal tissues in vitro were surprisingly small (unpublished results).

There is no general agreement on the physiological role of $P G$ synthesis in the developing fetal organs. If the PG synthetase-dehydrogenase system is regarded as 'burning out' enzymes (Lands, Le Tellier, Rome \& Vanderhoek, 1974), PGs would not be able to escape from the site of production, and would therefore be unlikely to be involved in the initiation of labour, or in the maintenance of uterine activity.

Our results with fetal human tissues are similar to those of Pace-Asciak (1977a, b) for sheep lung and kidney. During early fetal development, up to Week 18, PGF-2 $\alpha$ synthesis is dominant (overall vasoconstriction), but in lung and kidney there is then a change to the vasodilatory effect of PGE-2 dominance. PGDH could perhaps be regarded as regulating the endogenous PG level of the developing organ.

The changes of PG metabolism during organogenesis could mean a "critical prostaglandin period" in the developing organ, as suggested by Pace-Asciak (1977a, b), and could have practical consequences. The increasing use of PG synthetase inhibitors in the clinical management of premature labour and primary dysmenorrhoea could be important (Csapo, Csapo, Fay, Henzl \& Salau, 1973a, b; Zuckerman, Reiss \& Rubinstein, 1974; Anderson, Haynes, Fraser \& Turnbull, 1978; Karim \& Hillier, 1979). Premature uterine activity could be arrested by lowering the PG synthetase activity and the data accumulated so far appear to be promising. However, we consider that the problem should be further explored before allowing wide-scale use of non-steroidal anti-inflammatory drugs in the treatment of premature labour.

We are indebted to Dr John Pike, Upjohn Co., for the gifts of prostaglandins. This work was supported in part by WHO.

\section{References}

Anderson, A.B.M., Haynes, P.J., Fraser, I.S. \& Turnbull, A.C. (1978) Trial of prostaglandin-synthetase inhibitors in primary dysmenorrhoea. Lancet 1 , $345-348$. 
Csapo, A.I., Csapo, E.F., Fay, E., Henzl, M.R. \& Salau, G. (1973a) The delay of spontaneous labor by naproxen in the rat model. Prostaglandins 3, 827837.

Csapo, A.I., Csapo, E.F., Fay, E., Henzl, M.R. \& Salau, G. (1973b) The role of estradiol in the activation of the uterus during premature labor and the effect of naproxen, an inhibitor of prostaglandin synthesis. Prostaglandins 3, 839-846.

Falkay, G. \& Sas, M. (1977a) Metabolism of prostaglandin $F_{2}$ in early human placenta in vitro. Hormone Res. 8, 99-106.

Falkay, G. \& Sas, M. (1977b) Changes of the prostaglandin $\mathrm{F}_{2 a}$ metabolism in early human placenta. Experientia 33, 1011.

Falkay, G. \& Sas, M. (1978) Correlation between the concentrations of prostaglandin dehydrogenase and progesterone in the early human placenta. J. Endocr. 76, $173-174$.

Falkay, G., Herczeg, J. \& Kovács, L. (1978a) Effect of betamimetic isoxsuprine on prostaglandin biosynthesis in pregnant human myometrium in vitro. Life Sci. 27, 2689-2696.

Falkay, G., Herczeg, J. \& Sas, M. (1978b) In vitro prostaglandin biosynthesis in human pregnant uterus from arachidonic acid. Acta biol. med. germ. 37, 941-943.

Karim, S.M. \& Devlin, J. (1967) Prostaglandin content of amniotic fluid during pregnancy and labour. J. Obstet. Gynaec. Br. Commonw. 74, 230-234.

Karim, S.M. \& Hillier, K. (1979) Prostaglandins in the control of animal and human reproduction. Br. med. Bull. 35, 173-180.

Keirse, M.J.N.C. (1978) Biosynthesis and metabolism of prostaglandins in the pregnant human uterus. $A d v$. Prostaglandin Thromboxane Res. 4, 87-101.

Keirse, M.J.N.C. \& Turnbull, A.C. (1975) Metabolism of prostaglandins within the pregnant uterus. $B r . J$. Obstet. Gynaec. 82, 887-893.
Keirse, M.J.N.C., Williamson, J.G. \& Turnbull, A.C. (1975) Metabolism of prostaglandin $F_{2 n}$ within the human uterus in early pregnancy. $B r . J$. Obstet. Gynaec. 82, 142-145.

Lands, W.E.M., Le Tellier, P.R., Rome, L. \& Vanderhoek, J.Y. (1974) Regulation of prostaglandin synthesis. In Prostaglandin Synthetase Inhibitors, pp. 1-7. Eds H. J. Robinson \& J. R. Vane. Raven Press, New York.

Lowry, O.H., Rosebrough, N.J., Farr, A.L. \& Randall, R.J. (1951) Protein measurement with the Folinphenol reagent. J. biol. Chem. 193, 265-275.

Mitchell, M.D., Hicks, B.R., Thorburn, G.D. \& Robinson, J.S. (1978) Production of thromboxane $B_{2}$ by intra-uterine tissues from late pregnant Rhesus monkeys (Macaca mulatta) in vitro. J. Endocr. 79, 103-106.

Needelman, P. (1978) Experimental criteria for evaluating prostaglandin biosynthesis and intrinsic function. Biochem. Pharmac. 27, 1515-1518.

Pace-Asciak, C.R. (1977a) Prostaglandin biosynthesis and catabolism in the developing fetal sheep lung. Prostaglandins 13, 649-660.

Pace-Asciak, C.R. (1977b) Prostaglandin biosynthesis and catabolism in the developing fetal sheep kidney. Prostaglandins 13, 661-668.

Piper, P.J. \& Vane, J.R. (1971) The release of prostaglandins from lung and other tissues. Ann. N. Y. Acad. Sci. 180, 363-385.

Tai, H., Tai, C.L. \& Hollander, C.S. (1976) Biosynthesis of prostaglandins in rabbit kidney medulla. Biochem. J. 154, 257-264.

Willman, E.A. \& Collins, W.P. (1978) The metabolism of prostaglandin $E_{2}$ by tissues from the human uterus and foeto-placental unit. Acta endocr., Copenh. 87, $632-642$.

Zuckerman, H., Reiss, U. \& Rubinstein, I. (1974) Inhibition of human premature labor by indomethacin. Obstet. Gynec., N.Y. 44, 787-792. 